\title{
MODEL KONSELING RESOLUSI KONFLIK BERLATAR BIMBINGAN KOMPREHENSIF UNTUK MENGEMBANGKAN KOMPETENSI HIDUP DAMAI DAN HARMONI SISWA SMK*)
}

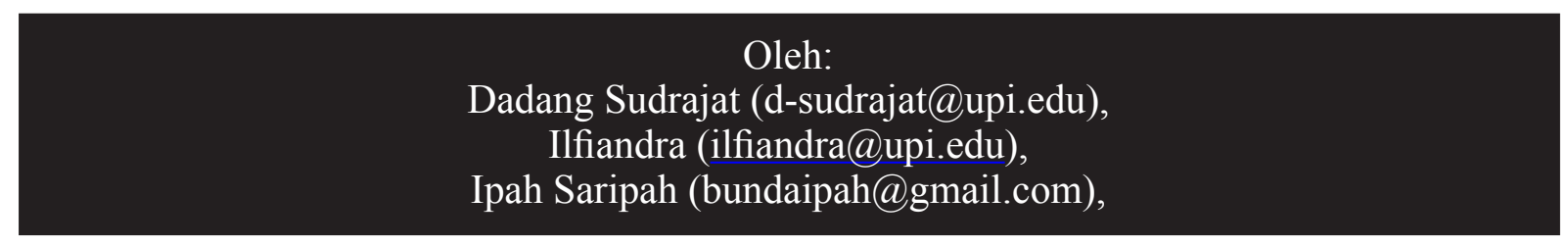

\begin{abstract}
ABSTRAK
Penelitian bertujuan merumuskan model konseling resolusi konflik berlatar bimbingan komprehensif untuk mengembangkan kompetensi hidup damai dan harmoni siswa SMK. Penelitian menggunakan pendekatan kuantitatif-kualitatif dengan metode riset pengembangan. Populasi penelitian adalah siswa SMK di kota Bandung dengan jumlah sampel 364 siswa, 4 orang konselor, dan 1 orang pakar intervensi BK. Hasil penelitian menunjukkan: (1) learning to be dan learning to live together adalah pilar yang tidak dapat diabaikan, sementara ada pandangan bahwa learning to live together sebagai pilar keunggulan; (2) secara umum kompetensi hidup damai dan harmoni siswa berada pada kategori tinggi namun aspek keharuan, harmoni, dan terima kasih masih perlu pengembangan; (3) resolusi konflik berada dalam payung pendidikan damai (peace education) satu gugus dengan perdamaian, rekonsiliasi, toleransi, penghargaan terhadap hak asasi, dan partisipasi sipil; (4) berdasarkan pertimbangan teoretis dan empiris, konseling resolusi konflik dapat menjadi alternatif solusi pengembangan kompetensi hidup damai dan harmoni siswa; dan (5) hasil validasi rasional menunjukkan bahwa model memiliki fisibilitas untuk diimplementasikan di sekolah.
\end{abstract}

Kata Kunci: konseling, resolusi konflik, bimbingan komprehensif, hidup damai dan harmoni.

\begin{abstract}
This study aimed at formulating a model of conflict-resolution counseling with comprehensive guidance ground for developing peace and harmony life competences of vocational high school students. Quantitative-qualitative approach with research and development method was used. Population of the research consisted of students of vocational high schools in Bandung Municipality with its sample amounting to 364 students, 4 counselors, and 1 expert of guidance and counseling intervention. Results showed: (1) learning to be and learning to live together were education pillars which were not neglected, where there is a view that learning to live together as a par excellent pillar; (2) Generally students' peace and harmony life competences were in high category but affection, harmony, and thanks giving aspects needed to be developed; (3) conflict resolution was under the umbrella of peace education, in a group with peace, reconciliation, tolerance, respect to human rights, and civil participation; (4) based on theoretical and empirical consideration, the conflict-resolution guidance with comprehensive guidance background was predicted to be able to become an alternative solution for developing students' peace and harmony life competences, and (5) validation results of a rational model that involved guidance and counseling experts and school counselors showed that the model had feasibility to be implemented at school.

Key words: counseling, conflict-resolution, comprehensive guidance, peace and harmony life.
\end{abstract}

\section{Pendahuluan}

Pada awal milenium, persoalan hidup bersama dalam damai dan harmoni semakin mengemuka sehingga menjadi tantangan semua elemen kehidupan termasuk dunia pendidik. Bagaimana siswa memperoleh pengetahuan dan keterampilan yang dapat mencegah dan menyelesaikan konflik, menjadi warga negara yang bertanggung jawab, dan mampu menjaga kesejahteraan diri dan orang lain merupakan pekerjaan rumah bagi dunia pendidikan. Hal ini sejalan 
dengan pandangan Jacques Delors (1996) sebagai ketua International Commissions on Education for the Twenty-first Century bahwa "...learning to live together, learning to live with others. This type of learning is probably one of the major issues in education today".

Beberapa pertanyaan reflektif yang menjadi bahan renungan dunia pendidikan adalah: (1) dapat kah generasi mudah memperoleh keterampilan dan nilai-nilai yang mendukung resolusi konflik tanpa kekerasan pada tingkat pribadi, sekolah, dan komunitas dihubungkan dengan penghormatan terhadap hak asasi manusia dan komitmen terhadap partisipasi sipil; (2) apakah pendidikan dapat membantu mengembangkan keterampilan dan nilai-nilai yang berkontribusi terhadap dunia yang lebih damai; dan (3) dapat kah pendidikan membantu membelajarkan generasi mudah untuk saling menghormati dan berhubungan tanpa tekanan.

Dalam World Education Forum di Dakar tahun 2000 telah disetujui bahwa pendidikan diharapkan dapat merespon tantangan abad 21, berupa: (1) semua generasi muda dan orang dewasa diharapkan memiliki akses yang sama terhadap belajar dan program kecakapan hidup; (2) meningkatkan mutu pendidikan dan hasil belajar khususnya dalam literasi, numerikal dan kecakapan hidup utama; dan (3) meningkatkan saling pengertian, damai, dan toleransi dalam rangka mencegah kekerasan dan konflik.

Sekolah sebagai sebuah sistem sosial merupakan tempat yang semestinya kondusif untuk mendukung proses belajar. Pembelajaran akan berjalan dengan baik jika lingkungan fisik dan psikologis kondusif, sebaliknya konflik dan kekerasan dalam lingkungan sekolah dapat berdampak negatif terhadap proses belajar siswa. Jika diperhatikan iklim sekolah tidak selamanya damai dan aman. Hal ini dikarenakan oleh seringnya terjadi konflik di sekolah, baik dalam bentuk sederhana maupun yang lebih serius. Konflik-konflik di sekolah dapat terjadi dalam berbagai bentuk, baik bersifat horizontal maupun vertikal. Konflik yang bersifat horizontal misalnya konflik antarsiswa (interpersonal conflict), antarkelompok siswa dalam satu sekolah, dan antara siswa dari satu sekolah dengan siswa dari sekolah lain. Apapun bentuknya, jika konflik hadir maka akan mengganggu proses belajar dan kemudian akan memperlemah proses dan prestasi belajar siswa.

Pada dasarnya konflik tidak perlu selalu dipersepsi secara negatif. Jika konflik dipersepsi secara positif dan diselesaikan secara konstruktif, konflik kemudian dapat menjadi sarana belajar dari pengalaman kehidupan nyata dan dapat membantu mengembangkan konsep diri siswa. Oleh karena itu, siswa mesti dididik dan dilatih pengetahuan, kesadaran, dan sikap serta keterampilan menyelesaikan konflik secara konstruktif. Sebagai dampaknya nanti para siswa diharapkan mampu menyelesaikan konflik mereka secara positif sepanjang waktu di sekolah dan dalam kehidupan bermasyarakat.

Terdapat beberapa inisiatif pendidikan yang dirancang untuk membantu orang belajar hidup bersama dalam damai dan harmoni. Namun sulit untuk mencari satu kata untuk upaya tersebut, misalnya "positive peace", pillar of sustainable 
development atau mengacu pada terminologi UNESCO dengan sebutan "learning to live together" atau "education for universal value". Pendidikan damai merupakan salah satu bentuk dari learning to live together yang memiliki beragam makna. Sebagai contoh, pendidikan damai berarti perubahan pola pikir untuk saling pengertian, respek, dan toleransi. Makna lainnya, pendidikan damai merupakan penguasaan sejumlah keterampilan tanpa kekerasan dan resolusi konflik, mediasi teman sebaya, dan program resolusi konflik.

American School Counselor Association (ASCA, 2002) berpandangan bahwa"program resolusi konflik dapat menciptakanlingkunganyang ramah sehingga mendorong bagi perkembangan pribadi dan belajar siswa. Dengan berpartisipasi dalam program resolusi konflik, siswa belajar keterampilan untuk memaksimalkan potensi guna mencapai tujuan pribadi dan keberhasilan di sekolah". Alasannya menurut Jhonson (1991) adalah kebanyakan siswa tidak mengetahui bagaimana mengelola konflik secara konstruktif.

Keberadaan pengajaran resolusi konflik sejalan dengan kedudukan dan peran siswa sebagai generasi muda yang diharapkan menjadi warga negara yang baik dan bertanggung jawab. Sebagai warga negara yang bertanggung jawab, para siswa mesti mampu memecahkan masalah apakah masalah mereka sendiri atau masalah masyarakat. Oleh karena itu, para siswa mesti dididik untuk menyelesaikan masalah termasuk ketika mereka menghadapi konflik di antara mereka sendiri. Jika para siswa tidak terlatih dan kurang mampu menyelesaikan konflik secara konstruktif, maka mereka cenderung menyelesaikannya secara destruktif. Deutsch dan Raider (Jones dan Kmitta, 2000) menyatakan bahwa "children who engage in destructive conflict strategies, particularly the use of violence, often have deficiencies in social problem-solving and interpersonal skills.

\section{Kajian Teoretis \\ Definisi dan Sumber Konflik}

Konflik merupakan salah satu bentuk interaksi sosial manusia. Deutsch (2000), seorang pelopor pendidikan konflik menyatakan bahwa "a conflict exists whenever incompatible activities accurs". Dalam konflik, interaksi sosial antarindividu atau kelompok lebih dipengaruhi oleh perbedaan daripada persamaan. Dalam situasi konflik, seseorang mungkin menghindari, mengalahkan, atau bahkan menghancurkan pihak lain. Coser (1967) mendefinisikan konflik sosial sebagai "a struggle over values or claims to status, power, and scarce resources, in which the aim as of the conflict group are not only to gain desired values, but also to neutralize injure, eliminate rivals".

Mengapa individu atau kelompok terlibat dalam konflik. Pertanyaan ini menggiring pada debat tentang sumber konflik. Semua perilaku manusia mempunyai sebab-sebab atau alasan yang memicu tindakan mereka. Oleh karena itu, konflik sebagai perilaku mempunyai sebab-sebab tertentu. Mengenai sumber konflik, ada pandangan yang menjelaskan sumber konflik sebagai sesuatu yang melekat dalam keturunan manusia. Dengan kata lain, perilaku konflik adalah suatu instink 
yang diwariskan. Pandangan ini berasal dari teori genetika konflik. Teori tentang sumber genetika konflik manusia berusaha menggambarkan bahwa agresi atau konflik diekspresikan secara spontan dan dengan demikian bukan hasil belajar (Jeong, 2000).

Dalam perspektif teori psikoanalisis tentang sumber konflik, seseorang individu atau kelompok menjadi musuh individu atau kelompok lainnya melalui suatu proses psikologis yang tak disadari yang dipengaruhi oleh polaritas positif dan negatif pada kesadaran diri awal. Sebagai organisme yang berorientasi tujuan, individu secara alamiah merasa sakit bila dicegah untuk mencapai apa yang mereka dambakan. Perilaku agresif atau konflik sering digunakan untuk melepaskan frustrasi seseorang. Jika perilaku agresif atau konflik tidak dapat diekspresikan terhadap sumber frustrasi yang nyata, maka objek pengganti dijadikan sasaran kemarahan pengganti.

Dalam perspektif kebutuhan dasar, manusia mempunyaikebutuhan dasarbiologis dan psikologis yang harus dipenuhi untuk kelanjutan hidup. Menurut Maslow terdapat lima kebutuhan, yaitu kebutuhan biologisfisiologis. Kebutuhan rasa aman, kebutuhan ras cinta dan rasa memiliki, kebutuhan harga diri, dan kebutuhan aktualisasi. Kebutuhan rasa aman, mencintai dan memiliki, penghargaan diri, dan aktualisasi diri merupakan kebutuhan-kebutuhan psikologis yang memandu perilaku dan interaksi sosial manusia. Jika kebutuhan manusia tidak dapat dipenuhi atau tertekan, maka perilaku konflik atau kekerasan sering terjadi. Banyak konflik yang merusak disebabkan oleh tidak terpenuhinya kebutuhan dasar manusia.
Dari sudut pandang sosiologi, konflik muncul karena tatanan sosial yang tidak adil dimana ada dominasi dan subordinasi yang memberikan kesempatan untuk eksploitasi. Ketidakpuasan ekonomi yang disebabkan oleh perubahan ekonomi dan sosial juga dapat memicu konflik sosial. Ketidakpuasan politik adalah faktor lain yang menyebabkan konflik sosial. Ketidakpuasan politik mungkin disebabkan oleh kekecewaan terhadap orang-orang di pusat kekuasaan, hak-hak yang tidak sama, tidak memiliki akses partisipasi politik, atau tidak memiliki kebebasan politik. Keluhan, protes, pemberontakan, reformasi, revolusi yang tercermin dalam konflik sosial sering disebabkan oleh ketidakpuasan ekonomi dan politik. Konflik sosial juga dipengaruhi oleh kelemahan atau kekuatan lembaga. Misalnya, masyarakat yang heterogen dalam hal etnis, ras, agama, bahasa, dan budaya tampaknya lebih mungkin untuk jatuh dalam konflik sosial daripada masyarakat yang homogen.

\section{Dampak Konflik terhadap Kondisi Psikologis Individu}

Konflik sosial, meskipun memiliki manfaat positif, seringkali membawa dampak negatif bagi pihak-pihak yang berkonflik, misalnya dalam bentuk kerugian harta benda dan nyawa. Konflik dapat membawa akibat yang kurang baik terhadap aspek kejiwaan atau psikologis seseorang. Seseorang yang tidak dapat menyelesaikan suatu isu atau masalah sosial yang kontroversial dapat mengganggu kesehatan mental. Menurut Hunt \& Metcalf (1995), kesehatan mental yang tergangguyang bersifat neurotik akibat ketidakmampuan mengatasi konflik dalam diri sendiri dapat 
terwujud dalam bentuk perilaku yang tidak alamiah, penolakan yaitu perilaku yang mengabaikan masalah, menekan masalah ke alam bawah sadar, menarik diri dari masalah, menyalahkan orang lain, bersifat kekanakkanakan dalam emosi dan intelektual, dan gangguan psikosomatis.

Pihak-pihak yang terlibat dalam konflik sosial, khususnya pihak yang merasa menjadi korban, seringkali mengalami berbagai gangguan psikologis, seperti perasaan dendam, curiga, kecewa, frustrasi, sakit hati, benci, stres, depresi, perasaan ketakutan, kehilangan rasa percaya diri, dan sebagainya. Dampak psikologis yang lebih berat adalah jika yang bersangkutan mengalami trauma psikologis yang mendalam. Jika sudah mengalami gangguan psikologis yang berat, maka penyelesaian konflik bukan sekedar melibatkan tindakan negosiasi, mediasi ataupun arbitrasi, tetapi juga melalui konseling traumatik pasca konflik sosial bagi korban yang mengalami gangguan psikologis.

\section{Bimbingan Komprehensif}

Model bimbingan komprehensif dikembangkan oleh Gysbers, et al. (1988) di Universitas Missouri, Columbia. Model bimbingan ini telah digunakan oleh sekolah di seluruh negara bagian Amerika Serikat yang bertujuan membantu pemerintah mengembangkan program bimbingan perkembangan untuk siswa Taman Kanakkanak sampai siswa SLTA secara sistematis dan komprehensif. Model ini memberikan bimbingan dengan materi pendidikan khusus dengan tujuan agar siswa dapat menguasai kompetensi-kompetensi tertentu.
Model bimbingan komprehensif memiliki dua bagian pokok, yaitu struktur dan program. Bagian struktur memiliki lima komponen yaitu definisi dan landasan filosofis, fasilitas, staf ahli/penasihat, sumber, dan pola staf dan keuangan. Struktur tidak mempunyai hubungan langsung dengan siswa tetapi berperan penting dalam memelihara integritas dan administrasi seluruh program bimbingan (Ellis, 1990). Sedangkan program memiliki empat komponen yaitu kurikulum bimbingan, perencanaan individual, layanan responsif, dan dukungan sistem (Muro \& Kotman, 1995). Kurikulum bimbingan berisi pengalaman-pengalaman perkembangan siswa yang terstruktur, disajikan secara sistematis melalui kegiatan-kegiatan kelas, bertujuan memberi wawasan kepada siswa mengenai pertumbuhan dan perkembangan hidup yang normal, meningkatkan kesehatan mental, dan membantu memperoleh keterampilan-keterampilan hidup. Kurikulum bimbingan ini ditata dalam bentuk eksplorasi dan perencanaan karir, pemahaman diri dan orang lain, dan pengembangan pendidikan. Komponen perencanaan individual berisi kegiatan-kegiatan yang membantu seluruh siswa menyusun tujuan, rencana, dan mengelola diri sendiri sehubungan dengan pengembangan pribadi dan karir. Komponen layanan responsif berisi kegiatan-kegiatan untuk memenuhi kebutuhan-kebutuhan jangka pendek siswa yang harus segera dipenuhi, apabila mereka memerlukan konseling, konsultasi, referal, atau informasi. Sedangkan komponen dukungan sistem berisi kegiatan-kegiatan manajemen yang bertujuan untuk memantapkan, memelihara, dan meningkatkan program bimbingan 
secara menyeluruh melalui pengembangan profesional, hubungan masyarakat dan staf, konsultasi dengan guru, staf ahli/penasehat, masyarakat yang lebih luas, manajemen program, penelitian dan pengembangan (Ellis, 1990).

Penelitian tentang efektivitas model bimbingan komprehensif diungkapkan oleh Gysbers, et al. (1988) bahwa sekolah-sekolah menengah tingkat atas di Alaska yang menerapkan model bimbingan komprehensif terbukti dapat membantu siswa memahami dirinya dan merencanakan karirnya. Hasil penelitian tersebut diperkuat oleh hasil penelitian Sheldon \& Morgan sebagai mana dimuat dalam Journal of Counseling and Developmental (1992), menunjukkan bukti bahwa model bimbingan komprehensif ini secara signifikan mampu meningkatkan prestasi belajar dan konsep diri siswa. Selanjutnya penelitian Sheldon \& Morgan (1992) menunjukkan bukti bahwa orang tua yang dilibatkan dalam program bimbingan komprehensif berbasis kompetensi ini mengatakan pendapatnya bahwa anak mereka memiliki sikap yang lebih positif terhadap sekolah dibandingkan dengan anak yang lainnya. Selanjutnya orang tua tersebut memberikan laporan bahwa setelah mereka terlibat dalam bimbingan komprehensif berbasis kompetensi, pemahaman mereka terhadap anaknya menjadi lebih baik dan mereka lebih berpartisipasi dalam pendidikan anaknya.

Sehubungan dengan strategi intervensi dalam bimbingan komprehensif, Bonebrake \& Borgers (1992) sebagaimana dimuat dalam Journal Counseling and Development mengemukakan hasil penelitiannya bahwa para kepala sekolah dan konselor sekolah tingkat atas sangat menekankan strategi konseling individual dan kelompok, bimbingan kelas, konsultasi dengan guru dan orang tua, serta koordinasi dalam program bimbingan. Selanjutnya penelitian Miller (988) menunjukkan bukti bahwa para konselor di sekolah tingkat dasar dan menengah di Amerika Serikat memandang penting strategi konseling dan konsultasi itu dalam program bimbingan komprehensif.

Konseling Resolusi konflik: Program Prevensi dan Intervensi

Pendidikan resolusi konflik sebaiknya ditempatkan sebagai program prevensi dan intervensi. Pendidikan resolusi konflik diberikan secara komprehensif dan terpadu yang bermuatan pengetahuan, sikap, dan keterampilan resolusi kepada siswa. Tanpa pemahaman yang baik tentang hakikat konflik dan bagaimana strategi penyelesaiannya, maka sulit bagi siswa untuk menyelesaikan konflik secara konstruktif. Pengetahuan resolusi konflik yang dapat dikembangkan melalui konseling antara lain meliputi: (1) pemahaman terhadap hakikat konflik, (2) konflik yang memanas dan respons terhadap konflik, (3) pemahaman terhadap upaya mengatasi rasa marah, dan strategi penyelesaian konflik.

Untuk memberikan kemampuan kepada siswa dalam menyelesaikan konflik tidak cukup hanya memberikan pengetahuan tentang konflik dan strategi penanganannya, melainkan juga sikap mereka terhadap resolusi konflik. Jika mereka memiliki sikap positif terhadap resolusi konflik, maka memungkinkan mereka cenderung untuk 
menyelesaikan konflik secara konstruktif. Sikap positif yang dapat dikembangkan melalui konseling resolusi konflik adalah: (1) memandang konflik sebagai hal positif sekaligus negatif, (2) rasa marah dapat dikendalikan, (3) keyakinan bahwa perasaan seseorang dapat dibaca, (4) keyakinan bahwa terdapat perbedaan persepsi seseorang dalam memandang sesuatu, (5) keyakinan pada kemampuan diri untuk menyelesaikan konflik, (6) keyakinan bahwa siswa mampu mempelajari strategi menyelesaikan konflik, (7) keyakinan bahwa siswa dapat menyelesaikan konflik tidak harus mengalah pada orang lain, (8) kecenderungan menyelesaikan konflik sendiri tanpa bergantung pada orang lain, (9) kesediaan menerima pihak ketika yang dapat membantu menyelesaikan konflik, (10) berkolaborasi dalam menyelesaikan konflik, (11) keyakinan "sama-sama menang" menjadi solusi dalam konflik. Selain pengetahuan dan sikap tentang konflik, dalam konseling resolusi konflik siswa dapat dibekali dengan berbagai keterampilan. Keterampilan yang dimaksud adalah (1) mendengarkan secara aktif, (2) menangani eskalasi konflik, (3) membaca dan memahami perasaan dan rasa marah, (4) memahami sudut pandang orang lain, (5) pemecahan masalah yang sama-sama menguntungkan, (6) negosiasi dan mediasi.

Konseling resolusi konflik mempunyai beberapa strategi umum, meliputi negosiasi, mediasi, dan arbitrasi (Dugan, 1996). Strategi ini bersifat tanpa kekerasan. Melalui negosiasi pihak-pihak yang berkonflik mencoba memecahkan sendiri konflik melalui sukarela, baik secara formal maupun informal. Mediasi adalah strategi resolusi konflik melalui pihak ketiga yang netral yang membantu pihak-pihak yang berkonflik untuk mengidentifikasi dan menyelesaikan masalah. Tugas utama mediator adalah menfasilitasi dialog antara pihak yang berkonflik. Sedangkan strategi arbitrasi juga melibatkan pihak ketiga, namun memiliki otoritas untuk menentukan hasil atau solusi konflik yang harus dipatuhi oleh pihak yang berkonflik. Implementasi konseling resolusi konflik di sekolah sejalan dengan kebijakan dan strategi pendidikan nasional jangka panjang, yaitu mendorong pendidikan perdamaian dan pendidikan global.

Inti dari konseling resolusi konflik adalah pemecahan masalah. Hal ini berarti konflik sebagai masalah sosial mesti ditangani pada sumbernya. Cara-cara tradisional dalam penyelesaian konflik, seperti menggunakan otoritas, kontrol, kekuasaan reaktif yang unilateral cenderung gagal. Oleh karena itu, perlu dilakukan perubahan paradigma resolusi konflik dari kerangka kekuasaan ke proses yang mencakup analisis yang menyeluruh terhadap sumber konflik. Perubahan paradigma ini hanya dapat dilakukan oleh pendidikan pada semua jenjang.

\section{Penelitian tentang Efektivitas Model Resolusi Konflik}

Pendidikan resolusi konflik, dengan beberapa pendekatan yang berbeda telah diterapkan secara luas di beberapa negara, khususnya di sekolah-sekolah di Amerika Serikat. Pendidikan resolusi konflik di sekolahsekolah Amerika Serikat telah terbukti mempunyai dampak positif terhadap siswa, sekolah, dan masyarakat (Jones \& Kmitta, 2000). 
Berdasarkan pengamatan, dalam sistem pendidikan di Indonesia dari taman kanak-kanak sampai perguruan tinggi secara eksplisit belum terdapat program resolusi konflik atau pendidikan perdamaian, apakah dalam bentuk program komprehensif ataupun melalui layanan khusus. Banyak studi telah dilakukan untuk mengetahui dampak pendidikan resolusi konflik. Beberapa penelitian menemukan bahwa pendidikan resolusi konflik berdampak terhadap siswa, sekolah, guru, dan orang tua, sementara penelitian lainnya menyatakan tidak. Pendidikan resolusi konflik berdampak positif terhadap prestasi akademik, keterampilan, dan kesehatan psikologis siswa. Studi Jhonson \& Jhonson (1996) menemukan bahwa resolusi konflik dan pelatihan mediasi sejawat dapat meningkatkan prestasi akademik. Pendidikan resolusi konflik dapat meningkatkan pengetahuan dan keterampilan siswa. siswa yang berpartisipasi dalam pelatihan resolusi konflik dapat mendemonstrasikan prosedur negosiasi dan mediasi. Mereka menggunakan prosedur negosiasi yang lebih konstruktif dalam memecahkan konflik setelah mengikuti pelatihan mediasi teman sejawat. Mereka juga menjadi penyelesai konflik yang istimewa dan mengembangkan rasa percaya diri terhadap kemampuannya, dan dapat membantu orang-orang yang berselisih untuk menyelesaikan kesalahpahaman.

Penelitian Thompson

menemukan bahwa resolusi konflik dapat meningkatkan keterampilan siswa dalam memecahkan masalah, berpikir kritis, membuat keputusan, dan meningkatkan keterampilan sosial, seperti menghargai keragaman, empati, kerja sama, menggali dan mengungkapkan perasaan. Temuan lain dari studi Thomson adalah siswa dapat mengembangkan pengertian tentang konsep konflik, menyesuaikan keterampilan untuk memenuhi kemampuan pribadi, meningkatkan keterampilan interpersonal dan kepemimpinan, dan menggunakan proses resolusi konflik" sama-sama menang" dalam kehidupan mereka.

Studi Jhonson \& Jhonson (1996) menemukan bahwa sebagai hasil pengajaran resolusi konflik, kemampuan siswa meningkat dalam memecahkan konflik secara konstruktif, kesehatan psikologis, penghargaan diri, pengaturan diri, kendali diri, ketegasan, dan ketahanan siswa. Studi Butler (2000) mendukung dampak positif dari pendidikan resolusi konflik, yaitu meningkatkan keterampilan pemecahan masalah dan konsep diri remaja. Remaja dalam studi ini menunjukkan peningkatan yang signifikan dalam konsep diri, baik konsep diri fisik maupun kesikapan. Kmitta (1999) menemukan bahwa mediasi sejawat mengurangi konflik pribadi dan meningkatkan kecenderungan untuk membantu orang lain dalam konflik, meningkatkan nilainilai prososial, meningkatkan kemampuan memahami perspektif orang lain, dan menurunkan agresivitas.

Secara ideal, program pendidikan resolusi konflik dapat meningkatkan iklim sekolah dan kelas yang kondusif bagi pembelajaran. Studi Jhonson \& Jhonson (1996) mengindikasikan bahwa pendidikan resolusi konflik mempunyai dampak positif dalam meningkatkan iklim sekolah. Terdapat penurunan pertengkaran antarsiswa dan berkurangnya kecenderungan pelanggaran 
disiplin, kekerasan, penyerangan, penahanan, dan skorsing. Pendidikan resolusi konflik mempunyai dampak positif bukan hanya pada siswa tetapi juga pada pendidik dan orang tua. Guru dan kepala sekolah menghabiskan sedikit waktu untuk menangani konflik antarsiswa dan lebih banyak waktu untuk kegiatan akademik, karena siswa mampu mengelola konflik secara konstruktif dan independen. Sebagian siswa mampu mentransfer kemampuan yang mereka pelajari di sekolah untuk memecahkan konflik-konflik non sekolah di rumahnya.

\section{Metode}

Penelitian menggunakan pendekatan kualitatif dan pendekatan kuantitatif dengan metode riset dan pengembangan. Populasi penelitian ini adalah para siswa SMKN 2 Kota Bandung dengan jumlah sampel 364 orang siswa. Selain siswa, penelitian ini juga melibatkan guru pembimbing sebagai responden untuk validasi rasional model dan mitra kolaborasi pada saat uji efektivitas model yang berjumlah 4 orang, dan pakar bimbingan dan konseling 1 orang. Instrumen untuk mengungkap kompetensi hidup damai dan harmoni siswa merujuk pada aspek dan indikator yang dikembangkan oleh UNESCO (2000) yang diungkap dengan skala model Thurstone. Analisis data menggunakan statistik deskriptif untuk menggabarkan profil kompetensi hidup damai dan harmoni. Analisis kualitatif digunakan untuk menafsirkan hasil validasi rasional model.

\section{Hasil}

1. Kajian teoretis tentang hidup damai dan harmoni

Hidup bersama dalam suasana yang penuh kedamaian dan keharmonisan adalah harapan semua umat manusia. Untuk mencapainya, diperlukan langkah strategis melalui proses belajar. UNESCO (2000: 8) menegaskan, bahwa: "belajar hidup bersama dalam damai dan harmoni adalah suatu proses yang dinamis, holistik dan sepanjang hayat di mana saling menghormati, mengasuh (mempedulikan) dan berbagi, keharuan, tanggung jawab sosial, solidaritas, kesediaan menerima dan toleransi kemajemukan antar perorangan dan antar kelompok (etnik, sosial, budaya, agama, nasional dan regional) didarah-dagingkan dan dipraktekkan bersama-sama untuk memecahkan masalahmasalah dan berusaha ke arah masyarakat yang adil dan bebas, damai dan demokratis". Secara detail, konsep belajar hidup bersama dalam damai dan harmoni dapat dilihat pada gambar 1.

2. Gambaran kompetensi hidup damai dan harmoni

Secara umum, kompetensi hidup damai dan harmoni siswa termasuk kategori sedang $(72 \%)$, dan sisanya termasuk sedang (28\%). Secara detail, kompetensi hidup damai dan harmoni siswa berdasarkan aspekaspeknya sebagai berikut: cinta $(93,00)$, keharuan $(44,89)$, harmoni $(60)$, toleransi $(94,30)$, peduli $(24,21)$, interdependensi $(71,19)$, pengenalan $(90.06)$, dan terima kasih $(25,12)$. Data ini menunjukkan bahwa aspek kompetensi keharuan, peduli, dan terima kasih perlu pengembangan. 


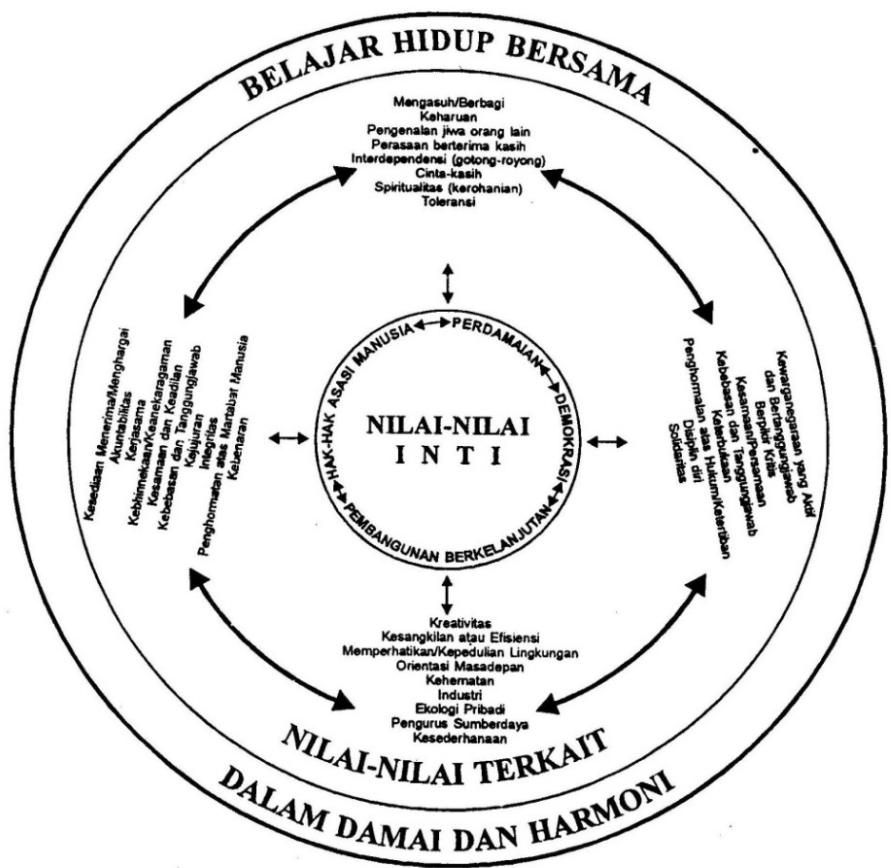

Gambar 1:Belajar Hidup Bersama: Diagram Skematis Perspektif Asia Pasifik tentang Nilai-nilai Inti dan yang Terkait yang Diperlukan untuk Hidup Bersama dalam Damai dan Harmoni

\section{Model konseling resolusi konflik}

berlatar bimbingan komprehensif untuk mengembangkan kompetensi hidup damai dan harmoni.

Berdasarkan pertimbangan teoretis dan empiris, konseling resolusi konflik berlatar bimbingan komprehensif diprediksi dapat menjadi alternatif solusi pengembangan kompetensi hidup damai dan harmoni siswa. Hasil pengembangan terwujud dalam bentuk model konseling resolusi konflik berlatar bimbingan komprehensif untuk mengembangkan kompetensi hidup damai dan harmoni siswa. Unsur-unsur model yang dikembangkan mencakup rasional, tujuan, prinsip, asumsi, fokus pengembangan, langkah-langkah, evaluasi dan indikator keberhasilan. Agar model dapat menjadi kerangka kerja operasional, maka dikembangkan manual yang mencakup deskripsi, langkah-langkah, prinsip reaksi, sistem sosial, sistem dukungan, dan dampak.

\section{Validasi rasional model}

Hasil validasi rasional model yang melibatkan pakar bimbingan dan konseling dan konselor sekolah menunjukkan bahwa model memiliki fisibilitas untuk diimplementasikan di sekolah, dengan pertimbangan bahwa hidup damai dan harmoni merupakan kebutuhan mendesak bagi siswa, konselor belum memiliki orientasi dan perspektif yang utuh mengenai hidup damai dan harmoni, dan keberadaan model beserta manual telah memenuhi spesifikasi suatu program dalam ilmu dan praktik layanan bimbingan dan konseling.

\section{Pembahasan}

Tantangan untuk hidup bersama dalam damai dan harmoni semakin tinggi, termasuk bagi kalangan pendidik. Siswa sendiri dihadapkan pula pada tantangan perilaku dalam kehidupan personal mereka. 
Bagaimana mereka memperoleh keterampilan mencegah dan menyelesaikan konflik, menjadi warga negara yang bertanggung jawab, dan mampu menjaga kesejahteraan diri dan orang lain merupakan tantangan bagi dunia pendidikan. Laporan dari International Commission on Education for Twenty-first Century, atau yang lebih dikenal dengan Delors Report telah mengidentifikasi tujuh ketegangan yang mengancam kemanusiaan yang berimplikasi langsung terhadap nilainilai, yaitu: antara global-lokal, universalindividual, tradisional-modern, pertimbangan jangka pendek-jangka panjang, kompetisikooperasi, ekspansi ilmu-kemampuan asimilasi, dan antara spiritual-material.

$$
\text { Komisi ini menyarankan }
$$

rekonseptualisasi pendidikan berdasarkan prinsip belajar sepanjang hayat yang ditopang oleh empat pilar: learning to know, learning to do, learning to be, dan learning to live together. Dua pilar pendidikan terakhir sering diabaikan oleh pendidikan atau tidak dipandang substantif. Dan komisi memandang bahwa learning to live together sebagai pilar penguat (pre-eminent). Jacques Delors (1996) sebagai ketua International commissions on Education for the Twentyfirst Century mengemukakan pandangan bahwa "...learning to live together, learning to live with others. This type of learning is probably one of the major issues in education today". Sejarah menunjukkan bahwa pendidikan tidak secara otomatis membawa pesan damai, demokrasi, dan menghormati hak dan kesejahteraan orang lain. Diperlukan upaya khusus agar pendidikan mengemban nilai-nilai tersebut (Smith \& Vaux, 2002).

Budaya damai merupakan proses aktif, positif, partisipatif dalam menghargai keragaman, toleransi terhadap perbedaan, mendorong upaya dialog, dan menyelesaikan konflik dengan semangat saling pengertian dan kerja sama (UNESCO). Proses ini berkembang secara berbeda pada setiap negara bergantung pada tradisi, budaya, dan agama. Oleh karena itu, budaya damai memerlukan proses jangka panjang dan multi dimensi melalui transformasi nilai, perilaku, orientasi hidup dalam semangat hidup bersama.

Beberapa pertanyaan reflektif yang menjadi tantangan bagi pendidikan adalah: (1) dapatkan generasi mudah memperoleh keterampilan dan nilai-nilai yang mendukung resolusi konflik tanpa kekerasan di tingkat pribadi, sekolah, dan komunitas dihubungkan dengan penghormatan terhadap hak asasi manusia dan komitmen terhadap partisipasi warga negara; (2) apakah pendidikan dapat membantu mengembangkan keterampilan dan nilai-nilai yang berkontribusi terhadap dunia yang lebih damai; (3) dapatkah pendidikan membantu membelajarkan generasi mudah untuk saling menghormati dan berhubungan tanpa tekanan.

Dalam World Education Forum di Dakar tahun 2000 telah disetujui bahwa pendidikan diharapkan dapat merespons tantangan abad 21, berupa: (1) semua generasi muda dan orang dewasa diharapkan memiliki akses yang sama terhadap belajar dan program kecakapan hidup; (2) meningkatkan mutu pendidikan dan hasil belajar khususnya dalam literasi, numerikal dan kecakapan hidup yang utama; (3) meningkatkan saling pengertian, damai, dan toleransi dalam rangka mencegah kekerasan dan konflik. 
Deklarasi Dakar bukan sesuatu yang baru, jauh sebelumnya dalam Convention on the Right of the child tahun 1989 telah ada kesepakatan yang diratifikasi oleh semua negara agar pendidikan mampu mempromosikan damai, hak asasi, dan tanggung jawab. Dalam pasal 29 deklarasi tersebut secara eksplisit dinyatakan bahwa pendidikan anak hendaknya diarahkan pada: (1) penghormatan terhadap hak asasi dan kemerdekaan, (2) penghargaan terhadap nilai-nilai tempat dimana mereka tinggal, berasal, dan dengan orang yang berbeda; (3) mempersiapkan anak menjadi pribadi bertanggung jawab yang dilandasi oleh semangat saling pengertian, damai, toleransi, dan persamaan; dan (4) penghargaan terhadap lingkungan.

Terdapat beberapa inisiatif pendidikan yang dirancang untuk membantu orang belajar hidup bersama dalam damai dan harmoni. Namun sulit untuk mencari satu kata untuk upaya tersebut, misalnya "positive peace", pillar of sustainable development atau mengacu pada terminologi UNESCO dengan sebutan "learning to live together" atau "education for universal value". Pendidikan damai memiliki beragam makna pada individu dari berbagai tempat. Sebagai contoh, sebagai perubahan pola pikir untuk saling pengertian, respek, dan toleransi. Makna lainnya, pendidikan damai sebagai penguasaan sejumlah keterampilan tanpa kekerasan dan resolusi konflik, mediasi teman sebaya, dan program resolusi konflik. Bagi dunia ketiga, pendidikan damai merujuk pada pengakuan terhadap hak asasi dan budaya damai. Dalam pendidikan damai, saling pengertian dan nilai hidup bersama dalam damai dan harmoni merupakan keterampilan inti. Betty Reardon dan Alicia Cabezudo (2002) mengemukakan kerangka kerja pendidikan damai yang diperuntukkan untuk pendidikan dasar dan menengah. Nilai-nilai anti kekerasan yang disinergikan dengan menghargai hak asasi, kebebasan, saling percaya, dan keadilan sosial yang diwujudkan melalui persamaan, tanggung jawab dan solidaritas. Tujuan pendidikan damai dapat dipandang sebagai spektrum yang terentang dari nilai dan keterampilan perilaku sampai pengertian internasional.

Pendidikan nilai berfokus pada penguatan perilaku pro-sosial yang dilandasi oleh sikap dan nilai peduli dan menghargai orang lain, kerjasama, dan tanggung jawab pribadi dan sosial. Nilai-nilai pokok yang dikembangkan adalah perdamaian, respek, cinta, toleransi, kebahagiaan, tanggung jawab, kerjasama, kemanusiaan, kebebasan dan persatuan. Program pendidikan nilai yang dikembangkan untuk kawasan Asia Pasifik meliputi harmoni dengan alam, kebenaran dan kebijaksanaan, cinta dan kasih sayang, kreativitas dan apresiasi terhadap keindahan, damai dan adil, persatuan nasional dan solidaritas global, spiritual global.

Pendidikan merupakan medium pokok pengembangan perdamaian, sekaligus merupakan fondasi, cornerstone dan komponen inti budaya damai. Unesco telah mempromosikan pendidikan perdamaian melalui: (1) mengembangkan kebijakan pendidikan yang menempatkan budaya damai dalam inti proses pendidikan, (2) meningkatkan metode dan isi pendidikan damai, (3) mempromosikan pendidikan multi budaya dan multi bahasa, 
pengembangan kapasitas guru melalui pelatihan pengembangan profesional; (5) saling tukar pengalaman praktik pendidikan untuk memperkuat kemitraan dan jejaring sosial.

Baru-baru ini,
mengembangkan $\quad$ program
budaya damai. Untuk itu, Asian-Pasific Programme of Educational Innovation for Development (APEID) telah melakukan riset mengenai nilai-nilai inti untuk hidup damai dan harmoni dalam sebuat draft buku. Setiap negara memiliki nilai-nilai yang berbeda bergantung pada tradisi dan tujuan pendidikan. Pendekatan yang digunakan juga beragam, seperti pengajaran langsung, preskriptif melalui open-ended, diskusi, klarifikasi nilai, dan pengkondisian.

Beberapa negara memposisikan pendidikan nilai sebagai bagian terpisah atau terintegrasi dalam kurikulum/infusi. Analogi yang digunakan adalah "in sweetened milk sugar is not visible but its presence is felt by its pleasant taste" atau menempatkannya sebagai pendidikan moral yang terpisah dari agama atau dalam perspektif eknomi/budaya. Pendekatan yang banyak digunakan adalah eksperensial, roleh playing, analisis nilai, klarifikasi nilai, diskusi nilai, value judgment. Pendidikan nilai merupakan bagian dari belajar. Oleh karena itu, pendekatan holistik diperlukan untuk hidup damai dan harmoni. Pendidik diharapkan memahami nilai sebagai "means and an end".

Dalam sistem pendidikan di Indonesia dari taman kanak-kanak sampai perguruan tinggi secara eksplisit belum terdapat program resolusi konflik atau pendidikan perdamaian, apakah dalam bentuk program komprehensif ataupun melalui layanan khusus. Banyak studi telah dilakukan untuk mengetahui dampak pendidikan resolusi konflik. Beberapa penelitian menemukan bahwa pendidikan resolusi konflik berdampak terhadap siswa, sekolah, guru, dan orang tua, sementara penelitian lainnya menyatakan tidak. Pendidikan resolusi konflik berdampak positif terhadap prestasi akademik, keterampilan, dan kesehatan psikologis siswa. Studi Jhonson \& Jhonson (1996) menemukan bahwa resolusi konflik dan pelatihan mediasi sejawat dapat meningkatkan prestasi akademik. Pendidikan resolusi konflik dapat meningkatkan pengetahuan dan keterampilan siswa. siswa yang berpartisipasi dalam pelatihan resolusi konflik dapat mendemonstrasikan prosedur negosiasi dan mediasi. Mereka menggunakan prosedur negosiasi yang lebih konstruktif dalam memecahkan konflik setelah mengikuti pelatihan mediasi teman sejawat. Mereka juga menjadi penyelesai konflik yang istimewa dan mengembangkan rasa percaya diri terhadap kemampuannya, dan dapat membantu orang-orang yang berselisih untuk menyelesaikan kesalahpahaman.

\section{Simpulan}

Tuntutan terhadap hidup damai dan harmoni semakin tinggi. Akan tetapi dunia pendidikan belum meresponnya secara sistematis. Hal ini terlihat dari empat pilar pendidikan yaitu learning to know, learning to do, learning to be, learning to live together, pilar yang terakhir cenderung tidak diabaikan, meskipun sudah 
ada perspektif baru yang menyatakan bahwa hidup bersama sebagai pilar keunggulan.

UNESCO telah mengembangkan berbagai inisiatif untuk hidup damai dan harmoni. Antara lain peace education, value education, citizenship education, human right education, dan life skills education. Terjadi diversifikasi terminologi, strategi, substansi dalam implementasi program pendidikan hidup bersama dalam damai dan harmoni, baik antarnegara, antar-etnis, bahkan antaragama. Posisi resolusi konflik berada dalam payung pendidikan damai (peace education) satu gugus dengan perdamaian, rekonsiliasi, toleransi, penghargaan terhadap hak asasi, dan partisipasi sipil.

Secara umum kompetensi hidup damai dan harmoni siswa berada pada kategori tinggi dengan merujuk pada nilainilai yang telah dirumuskan oleh UNESCO melalui Asian-Pasific Programme of Educational Innovation for Development (APEID), meskipun pada aspek keharuan, harmoni, dan terima kasih masih perlu pengembangan.

Berdasarkan pertimbangan teoretis dan empiris, konseling resolusi konflik berlatar bimbingan komprehensif diprediksi dapat menjadi alternatif solusi pengembangan kompetensi hidup damai dan harmoni siswa. Hasil pengembangan terwujud dalam bentuk model konseling resolusi konflik berlatar bimbingan komprehensif untuk mengembangkan kompetensi hidup damai dan harmoni siswa. Unsur-unsur model yang dikembangkan mencakup rasional, tujuan, prinsip, asumsi, fokus pengembangan, langkah-langkah, evaluasi dan indikator keberhasilan. Agar model dapat menjadi kerangka kerja operasional, maka dikembangkan manual yang mencakup deskripsi, langkah-langkah, prinsip reaksi, sistem sosial, sistem dukungan, dan dampak.

Hasil validasi rasional model yang melibatkan pakar bimbingan dan konseling dan konselor sekolah menunjukkan bahwa model memiliki fisibilitas untuk diimplementasikan di sekolah, dengan pertimbangan bahwa hidup damai dan harmoni merupakan kebutuhan mendesak bagi siswa, konselor belum memiliki orientasi dan perspektif yang utuh mengenai hidup damai dan harmoni, dan keberadaan model beserta manual telah memenuhi spesifikasi suatu program dalam ilmu dan praktik layanan bimbingan dan konseling.

\section{Referensi}

Borders, Anne, L. D. \& Drury, S. M. (1992). "Comprehensive School Counseling Programs: A Review for Policymakers and Practitioners". Journal of Counseling and Development 70, 487495.

Creswell, J.W. (1994). Research Design: Qualitative and Quantitative Approaches. London: Sage Publications.

D’Andrea, M. (2004). “Comprehensive Schoo-Based Violen Prevention Training: A Developmental Ecological Training Model". Journal of Counseling and Development 82, 277.

Delors, J. (1996). Learning: The Treasure Within. Paris. UNESCO Publishing. Morton, D. (2000). Cooperation and Competition, dalam The Handbook of Conflict Resolution Theory and 
Practice. San Francisco: Jossey-Bass

Publishers.

Dugan. (1996). A Nested Theory fo Conflict,

A Leadership Journal: Women in

Leaderships, 1, 9-20.

Ellis, T. I. (1990). The Missouri Comprehensive Guidance Model. Columbia: The Educational Resources Information Center.

Haar, B.F. dan Krahe. 1999. Strategies for Resolving Interpersonal Conflict in Adolescence, A German-Indonesia Comparison, dalam Journal of CrossCultural Psychology, 30, 667-683.

Henderson, P. (1988). A Comprehensive School Guidance Programe at Work. Texas Association for Counseling and Development Journal, 15, 25-27. Jeong, Ho-Won, (2000). Peace and Conflict Study: an Introduction:UK: Ashgate. Jhonson, D.W. dan Jhonson, R.T. (1996). Conflict Resolution and Peer Mediation Program in Elementary and Secondary Schools : A Review of The Research, Review of Educational Research, 66, 459-506.

Jones, B., Kmitta, D. (1999). Looking for Success: Evaluating Peer Mediation and Conflict Resolution Education Program. A Workshop for the Ohio Commission for Dispute Resolution, 1999-2000.

Jones, B., Kmitta, D. (2000). Does It Works?

The Case for Conflict Resolution

Education in Our Nation's School.

Washington: Conflict Resolution

Education Network.

Kantor Prinsipal UNESCO untuk Kawasan Asia-Pasifik Bangkon dan Universitas
Pendidikan Indonesia. (2000). "Belajar untuk Hidup Bersama dalam Damai dan Harmoni: Pendidikan Nilai untuk Perdamaian, Hak-hak Asasi Manusia, Demokrasi, dan Pemban gunan Berkelanjutan untuk Kawasan AsiaPasifik". Buku Sumber UNESCOAPNIEVE untu Pendidikan Guru dan Jenjang Pendidikan Tinggi. Bandung: Universitas Pendidikan Indonesia.

Kleden, I. (2002). Arkeologi Perdamaian (Online). Tersedia di:http/www. kompas.com.

Muro, J.J. \& Kottman, T. (1995). Guidance and Counseling in The Elementary and Middle Schools. Madison : Wm C.Brown Com.Inc.

Myrick, Robert. 11993. Developmental Guidance and Counseling: A Practical Approach. Minneapolis: Educational Media Corporation.

Shertzer, B. \& Stone, S, C., (1971). Fundamental of Guidance. New York : Houghton Mifflin Company.

Stevens, J., \& Jhonson, R.T. (2000). Effect of Conflict Resolution Training Integrated into a Kindergarten Curriculum, Child Development, May/ June, Volume 71, Number 3, 772-784.

Sugiyono . (2006). Metode Penelitian Kuantitatif, Kualitatif, dan R\&D. Bandung: Alfabeta.

Walter, I. (1992). Understanding Conflict and the Science of Piece. Cambridge, MA: Blackwell.

Warnwen, S. (2002). Stereoptip Etnis dalam Masyarakat Multietnis. Yogyakarta: Mata Bangsa. 